\title{
Hypokaliuria - a Neglected Variable in the Equation of Lithogenesis in Young Patients?
}

\begin{abstract}
DRAGOS PUIA ${ }^{1,2}$, TIBERIU PAUL NEAGU3,4, FLAVIA LILIANA TURCU5,6, RAZVAN ION FLORIN DRAGOMIRESCU5,6, MIRELA TIGLIS ${ }^{7,8}$, CATALIN PRICOP1,2*

${ }^{1}$ Gr. T. Popa University of Medicine and Pharmacy, Department of Urology, $16^{\text {th }}$ Universitatii Str., 700115, lasi, Romania 2Department of Urology and Renal Transplant, Dr. C.I. Parhon Clinical Hospital, 50 ${ }^{\text {th }}$ Carol I Blvd., 700503 Iasi, Romania ${ }^{3}$ Carol Davila University of Medicine and Pharmacy, Clinical Department No. 11, $8^{\text {th }}$ Eroii Sanitari Str., 050474, Bucharest, Romania ${ }^{4}$ Department of Plastic Surgery and Reconstructive Microsurgery, Emergency Clinical Hospital of Bucharest, $8^{\text {th }}$ Floreasca Av., 014461, Bucharest, Romania

${ }^{5}$ Carol Davila University of Medicine and Pharmacy, Clinical Department No. 3, $8^{\text {th }}$ Eroii Sanitari Str., 050474, Bucharest, Romania ${ }^{6}$ St. J ohn Emergency Clinical Hospital, Department of Nephrology and Dialysis, 13 ${ }^{\text {th }}$ Vitan-Barzesti Road, 042122, Bucharest, Romania

${ }^{7}$ Carol Davila University of Medicine and Pharmacy, Clinical Department No. 14, $8^{\text {th }}$ Eroii Sanitari Str., 050474, Bucharest, Romania ${ }^{8}$ Department of Anesthesiology and Intensive Care, Emergency Clinical Hospital of Bucharest, $8^{\text {th }}$ Floreasca Av., 014461, Bucharest, Romania
\end{abstract}

Nephrolithiasis in young patients is today a public health problem with an increasing prevalence in industrialized nations. Between 01 January 2016 and 1 September 2018, we have evaluated patients aged between 18 and 40 years old referred to our clinic and diagnosed with urinary stones. After 30 days at least, it was confirmed using imaging stone-free status of the patient and then the 24h urine composition was performed. We have enrolled 110 patients, 58 males and 52 females, with a mean age of 29.55 years. Surprisingly, in 71 cases (64.54\%), patients had hypokaliuria, 37 normokaliuria cases (33.63\%) and two cases of hyperkaliuria (1.81\%). We divided the patients into two main groups: those with hypokaliuria and those without. In those with hypokaliuria, the mean concentration was $22.53 \mathrm{mmol} / \mathrm{L}$, while in the other group $52.77 \mathrm{mmol} / \mathrm{L}$. Patients with low urinary potassium level had a slightly acid urinary pH (5.6 vs. 5.86) and lower urinary density $\left(1012.96 \mathrm{vs} .1016 .15 \mathrm{~kg} / \mathrm{m}^{3}\right)$ than in others, however higher than the recommended levels in lithiasic patients. Urinary magnesium level was lower (3.68 mmol/24h vs $3.87 \mathrm{mmol} / 24 \mathrm{~h}$ ) in the hypokaliuria group. Therefore, hypokaliuria was positively correlated with two protective factors. Patients with hypokaliuria revealed low urinary levels of lithogenic factors. Natriuria was significantly lower in patients with hypokaliuria (67.81 vs. $120.77 \mathrm{mmol} / \mathrm{L}, p<0.05)$. In addition, we noticed the same thing on urinary calcium level (4.02 $\mathrm{mmol} / 24 \mathrm{~h}$ vs $4.98 \mathrm{mmol} / 24 \mathrm{~h})$ but with no statistical significance $(p=0.16)$. Hypophosphaturia was more common in those with hypokaliuria (18.89 vs. $26.72 \mathrm{mmol} / 24 \mathrm{~h}, p<0.05)$. The 24-hour urine analysis remains an important component of the metabolic workup for recurrentrenal lithiasis. It seems that many of the young lithiasic patients in our geographic area have a low urinary potassium. Paradoxically, patients with hypokaliuria seems to have also hyponatriuria and hypophosphaturia. Through this study, we hope to make correlations between the risk of recurrent lithiasis -being a recognized high risk among young patients - and changes in 24-hour urine parameters found in the initial assessment.

Keywords: hypokaliuria, 24h urine collection, nephrolithiasis.

Nephrolithiasis in young patients is today a public health problem with an increasing prevalence in industrialized nations. According to Sorokin I. etal. worldwide prevalence ranges between $7-13 \%$ in North America, 5-9\% in Europe, and $1-5 \%$ in Asia [1,2]. Fink H.A. et al. estimated 5-year recurrence rate of approximately $50 \%$ [3]. Other metabolic imbalances will occur at this patients' age, especially in women [4-6]. Based on the complex thermogravimetric findings and porosity studies of renal stones, Tanasescu R.N. etal. showed a connection between postmenopausal osteoporosis and the risk of worsening calcium balance in urolithiasis [7]. The 24-hour urine collection plays an important role in kidney stone prevention by detecting metabolic abnormalities. By identifying specific urine composition abnormalities, the clinician would be able to make individualized diet and pharmacological interventions to correct these abnormalities and reduce the recurrence risk. Although it appears that urinary potassium is not involved in lithogenesis, we wanted to highlight a correlation between the level of urinary potassium and other lithogenic factors.

\section{Experimental part \\ Material and methods}

Between 01 January 2016 and 1 September 2018, we have evaluated patients aged between 18 and 40 years old referred to our clinic and diagnosed with urinary stones. Urinary lithiasis was confirmed by sonographic and/or radiologic investigations. They received medical or surgical treatment and after at least 30 days, when it was confirmed using imaging the stone-free status of the patient, the 24hour urine composition was performed. The patients did not have chronic medication or did not take dietary supplements containing potassium. The patients received a glass recipient and instructions on how to collect and store the urine. They were also advised to have a regular diet on the day when they collected the urine. Statistical analysis was made using Student t-Test for 2 Independent Means and Chi-Square test, calculated online on http:// www.socscistatistics.com/tests/Default.aspx, while statistical significance was defined as $p$ value $\leq 0.05$. 


\section{Results and discussions}

We have enrolled 110 patients, 58 males and 52 females with a mean age of 29.55 years ( $S D=2.43$ ). Most of them $(66.45 \%, n=72)$ passed the stone, while in 38 cases urological intervention was required (PCNL in 7 cases, retrograde ureteroscopy in 13 cases and EWSL in 18 cases). Surprisingly, in 71 cases (64.54\%), patients had hypokaliuria, 37 normokaliuria cases (33.63\%) and two cases of hyperkaliuria (1.81\%) as shown in figure 1.

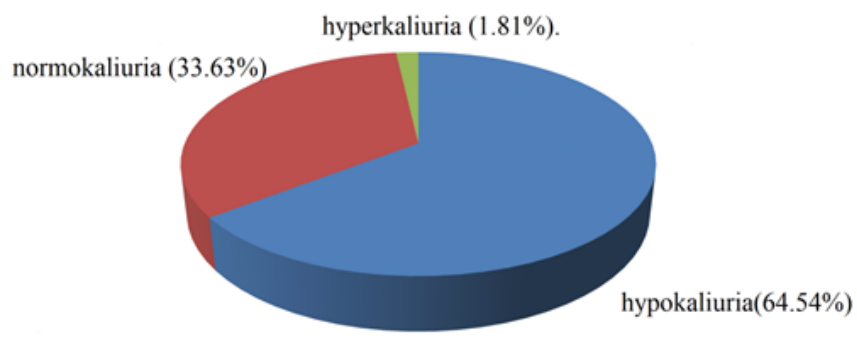

Fig. 1: Patient distribution based on urinary potassium level

We divided the patients into two main groups: those with hypokaliuria and those without. In those with hypokaliuria, the mean concentration was $22.53 \mathrm{mmol} / \mathrm{L}$, while in the other group $52.77 \mathrm{mmol} / \mathrm{L}$. We did not notice significant differences between the two groups in terms of average age or gender distribution, as shown in table 1.

Patients with low urinary potassium level had a slightly acid urinary $\mathrm{pH}$ (5.6 vs. 5.86) and lower urinary density (1012.96 vs. $1016.15 \mathrm{~kg} / \mathrm{m}^{3}$ ) compared to others, however higher than recommended level in lithiasic patients. Urinary magnesium level was lower $(3.68 \mathrm{mmol} / 24 \mathrm{~h}$ vs $3.87 \mathrm{mmol} / 24 \mathrm{~h}$ ) in the hypokaliuria group. Therefore, hypokaliuria positively correlated with two protective factors. Patients with hypokaliuria demonstrated low urinary levels of lithogenic factors. Natriuria was significantly lower in patients with hypokaliuria (67.81 vs. $120.77 \mathrm{mmol} / \mathrm{L}, \mathrm{p}<0.05)$. In addition, we noticed the same thing on the urinary calcium level $(4.02 \mathrm{mmol} / 24 \mathrm{~h}$ vs 4.98 $\mathrm{mmol} / 24 \mathrm{~h})$, but with no statistical significance $(p=0.16)$. Hypophosphaturia was more common in those with hypokaliuria (18.89 vs. $26.72 \mathrm{mmol} / 24 \mathrm{~h}, \mathrm{p}<0.05$ ), as shown in the table 2.

For a long time, renal nephrolithiasis has been considered an organ confined disease, today it is increasingly evident that it is a disease of the whole organism. Nagy E.N. et al. evaluated patients with lithiasis of the urinary tract and salivary gland, and after chemical analysis of the stones the authors found that the most encountered composition was the mixture of calcium oxalate and phosphate in cases where urinary and salivary gland stones were identified [8].

The purpose of clinical and metabolic evaluation of lithiasic patients is to prevent lithiasis recurrence, stop the growth of existing calculi and reduce the need for surgery. According to Chapple C. and Chandhoke P.S., every patient with a previous history of lithiasis should undergo a metabolic assessment $[9,10]$. The analysis of $24 \mathrm{~h}$ urine collections in the high-risk individuals is recommended both by European and American Urological Associations guidelines [11-13]. However, His R.S. et al. highlights that $24 \mathrm{~h}$ urine analysis have many drawbacks like complexity in interpretation, limited ability to predict recurrence and it may require repeated testing or cost-effectiveness [14]. More than that, stone formers can have normal 24-hour urine collections and non-stone formers can have abnormal collections, raising the question of whether current laboratory cutoff parameters are appropriate. According to Chapple C. et al. the metabolic assessment should be

\begin{tabular}{|l|l|l|l|}
\hline Variable & Hypokaliuria & Normo/hyperkaliuria & $\mathrm{p}$ \\
\hline $\mathrm{N}$ & $71(64.54 \%)$ & $39(35.46 \%)$ & \\
\hline Mean age (years) & $29.76(\mathrm{SD}=2.76)$ & $29.18(\mathrm{SD}=2.24)$ & 0.321067 \\
\hline Gender & 37 Females / 34 Males & 15 Females / 24 Males & 0.170106 \\
\hline
\end{tabular}

Table 1

AGE AND GENDER DISTRIBUTION

\begin{tabular}{|l|l|l|l|}
\hline Variable & Hypokaliuria & Normo/hyperkaliuria & $\mathrm{p}$ \\
\hline Urine density $\left(\mathrm{kg} / \mathrm{m}^{3}\right)$ & 1012.96 & 1016.15 & 0.000669 \\
\hline Volume (ml) & 1777.04 & 1397.95 & 0.000801 \\
\hline Proteins & abs & abs & \\
\hline Glucose & abs & abs & \\
\hline Urinary pH & & & 0.157105 \\
\hline Na (mmol/1) & 5.6 & 5.86 & 0.00001 \\
\hline $\mathrm{K}(\mathrm{mEq} / 24 \mathrm{~h})$ & 67.81 & 120.77 & \\
\hline $\mathrm{Cl}(\mathrm{mEq} / 24 \mathrm{~h})$ & 22.53 & 52.77 & 0.00001 \\
\hline Phosphates (mEq/24h) & 18.89 & 26.72 & 0.000026 \\
\hline $\mathrm{Mg}(\mathrm{mmol} / 24 \mathrm{~h})$ & 3.68 & 3.87 & 0.348364 \\
\hline Ca & 4.02 & 4.98 & 0.166971 \\
\hline
\end{tabular}

Table 2

URINE PARAMETERS IN THE TWO GROUPS 
performed at least one month after the elimination of the calculation to allow the body to return to its initial status. By collecting blood or urine during the acute lithiasic episode (obstruction, infection, renal colic), irrelevant information may be obtained $[9,15]$.

Rao N.P. et al. recommends that urine potassium levels should be monitored in stone formers [16]. Sriboonlue P. et al. were among the first to associate hypokaliuria with renal lithiasis. He compared the urinary potassium and citrate level of patients known with lithiasis with the ones of those without lithiasis, noting significantly lower levels in those with lithiasis [17]. There could be a link between urinary potassium and citrate in lithiasic patients. According to Mahle J.L. et al. decreased potassium may lead to hypocitraturia by intracellular acidosis [18, 19]. Also, according to Rao N.P. et al. a hypokalemic state, which can promote hypocitraturia, may be reûected in urinary potassium levels [14].

One of the major risk factors for stone disease is a concentrated urine, secondary to a low urine volume, which raises the supersaturation of all stone-forming salts. Both American and European guidelines on lithiasis recommends an over $2000 \mathrm{~mL} 24 \mathrm{~h}$ urine volume, furthermore, Borghi $\mathrm{L}$. et al. had shown that a urinary volume level of $2500 \mathrm{~mL}$ per day may reduce stone risk, while urine volumes over this amount can decrease stone risk even further [20]. In our study, although the patients with hypokaliuria had a significantly higher urine volume, the mean value was lower than $2000 \mathrm{~mL} / 24$ hours.

Urinary potassium levels are related to urinary sodium. Calciuria correlates with the prevalence of urinary lithiasis. Natriuria and kaliuria have antagonistic roles regarding calciuria. Heidelberg I.P. et al. showed that for every 100 mmol increase in dietary sodium, urinary calcium excretion will increase by $25 \mathrm{mg}[21,22]$. The increase in sodium excretion correlates with the increase in calcium while rising the concentration of urinary potassium, decreases the one of the urinary calcium [23]. According to Cirillo M. etal. an increased natriuria/kaliuria ratio is associated with an increased risk of urinary lithiasis [24].

Physiologically, human urine has a pH between 4.5 and 8.0. Urine $\mathrm{pH}$ is an important lithogenic factor as changes in urine $\mathrm{ppH}$ can drive crystallization of certain salts. The crystallization of some urine components like calcium phosphate, calcium oxalate, uric acid, cystine, and struvite are $\mathrm{pH}$ dependent. A patient with a urine $\mathrm{pH}$ below 5.5 has a great risk to develop uric acid stone, while on the other hand calcium phosphate crystals form in an alkaline environment of 6.5 and above. The most common lithiasis type, calcium oxalate, typically is not as $\mathrm{pH}$ dependent as the others. According to Corder C.J . et al., the average urine $\mathrm{pH}$ over a $24 \mathrm{~h}$ period should fall between 5.7 and 6.3, which limits $\mathrm{pH}$ dependent stone formation [25].

Eisner B.H. et al., have described that one of the most common metabolic abnormality associated with urolithiasis is hypercalciuria. It is defined as the urinary excretion of more than $0.1 \mathrm{mmol} / \mathrm{kg} / 24 \mathrm{~h}$ of calcium (or more than $4 \mathrm{mg}$ calcium $/ \mathrm{kg} /$ day) in an individual on normal diet, although some investigators use higher levels to define hypercalciuria in men (> 250-300 mg/day) and women (> 200-250 mg/day) [26]. In some patients hypercalciuria is secondary to some diseases like parathyroidism, renal tubular acidosis, Paget disease, paraneoplastic syndromes and Addison disease, while in other cases is idiopathic but dependent on dietary calcium, sodium or protein intake [27]. Moderate calcium intake is typically recommended to limit urinary excretion while maintaining bone health.
According to Daudon M. et al. a calciuria concentration above $3.8 \mathrm{mmol} / \mathrm{L}$ could be considered an independent lithogenic risk factor [28]. In our study, only patients with normal or high urinary potassium had a mean value slightly greater than $3.8 \mathrm{mmol} / \mathrm{L}$, while in those with hypokaliuria, it is possible that urinary calcium is not an independent risk factor.

The role of urinary magnesium in preventing stone formation has been debated for decades. Preminger G.M. et al. found a low incidence of hypomagnesuria in stone formers, which we also found in our study, and for this reason it has not been considered an important inhibitor of lithogenesis, although Robertson W.G. etal. demonstrated that magnesium binds urinary oxalate and recently Hussein N.S. etal. found hypomagnesuria in quite a high percentage (59.3\%). Calcium oxalate stone formation may thereby be inhibited [29-31]. According to Rao N.P. etal. supplemental magnesium therapy may also increase urinary citrate excretion by downregulating its tubular reabsorption [14]. Although our patients had a normal mean urinary magnesium it could be low in conditions associated with abuse of laxative medication, poor nutritional status, and some malabsorption syndromes [32,33].

According to Wu W. etal., excretion of urinary phosphate has been regarded as a risk factor for stone formation and recurrence. In a group of 500 Chinese patients, the authors found hyperphosphaturia only in $2.8 \%$, the overall mean urine phosphate was $17.2 \mathrm{mmol} / 24 \mathrm{~h}$, slightly lower as in our hypokaliuric patients [34]. According to Tiselius H.G. et al. a value $>50$ in conjunction with urinary $\mathrm{pH}$ it could be used to indicate an increased risk of forming a urine supersaturated with calcium phosphate [35]. In our study the mean urinary phosphate was in normal range in both groups, but significantly lower in those with hypokaliuria.

Overall, some of the modification of the 24 hour urine composition in our patients could be age-related. Friedlander J.I. et al. evaluated a total of 1115 patients divided into age groups consisting of $<45$ years $(19.7 \%)$, $45-54.9$ years $(23.8 \%), 55-64.9$ years $(24.6 \%)$, and $\geq 65$ years $(31.9 \%)$. Patients < 45 years who had a significantly lower mean urinary potassium $(54.8 \mathrm{mEq})$, they were also found with significant increasing trends with aging for potassium, and urine volume, while mean $\mathrm{pH}$, calcium, uric acid, phosphate, creatinine and protein catabolic rate decreased with age [36].

One of the major drawbacks of our study was the inability to perform the chemical analysis of the stone, therefore, we could not correlate the biochemical changes of the urine with the composition of the stone.

\section{Conclusions}

The $24 \mathrm{~h}$ urine analysis remains an important component of the metabolic workup for recurrent stone formers. It seems that many of the young lithiasic patients in our geographic area have a low urinary potassium. Paradoxically, patients with hypokaliuria seems to have also hyponatriuria and hypophosphaturia. Although 24-hour urine collection is considered an imperfect tool for predicting stone recurrence, every young lithiasis patient should undergo a metabolic evaluation because treatment based on this analysis is superior to empirical or nonselected therapy. Through this study, we hoped to make correlations between the risks of recurrent lithiasis (recognized as significant among young patients) and changes in $2 \mathrm{~h}$ urine parameters found in the initial assessment. 


\section{References}

1.SOROKIN I., MAMOULAKIS C., MIYAZAWA K., RODGERS A., TALATI J., LOTAN Y., World J. Urol., 9, nr. 35, 2017, p. 1301

2.PRICOP, C., NEGRU, I., CIUTA, C., JINGA, V., ILIE'IU, A., CHECHERITA, I.A., TODOSI, L., RADAVOI, D., JINGA, M., Farmacia, 64, nr. 5, 2016, p. 757

3.FINK H.A., WILT T.J ., EIDMAN K.E., GARIMELLA P.S., MACDONALD R., RUTKS I.R., BRASURE M., KANE R.L., OUELLETTE J ., MONGA M., Ann Intern Med., 7, nr. 158, 2013, p. 535

4.NICULESCU, D.A., BACIU, I.F., CAPATINA, C., GALOIU, S.A., GHEORGHIU, M.L., RADIAN, S., TRIFANESCU, R.A., CARAGHEORGHEOPOL, A., COCULESCU, M., POIANA, C., Endokrynol Pol., 68, nr. 5, 2017, p. 519

5.CAPATINA, C., RADIAN, '., BACIU, I., GHINEA, A., DECIU, D., DUMITRASCU, A., CIUBOTARU, V., POIANA, C., Acta Endocrinol (Copenh.), 12, nr. 4, 2016, p. 481

6.CAPATINA, C., CARAGHEORGHEOPOL, A., BERTEANU, M., POIANA, C., Exp. Clin. Endocrinol. Diabetes, 124, nr. 8, 2016, p. 461

7.TANASESCU, R.N., BARDAN, R., LEDETI, A., LEDETI, I., MATUSZ, P., BALINT, G.S., BOLINTINEANU, S.L., Rev. Chim. (Bucharest), 68, no. 6, 2017, p. 1357

8.NEMES NAGY, E., TILINCA, M.C., IACOB, A., ORMENISAN, A., FAZAKAS, Z., BARBU, H.M., KOLCSAR, M., MAIER, A.C., VIDA, A.O., MARTHA, O., Rev. Chim. (Bucharest), 68, nr. 4, 2017, p. 680

9.CHAPPLE, C.R., STEERS, W.D., Practical Urology: Essential Priciples and Practice, Springer-Verlag London Limited 2011

10.CHANDHOKE, P.S.. Urol. Clin. North Am., 3, nr. 34, 2007, p. 315

11.PEARLE, M.S., GOLDFARB, D.S., ASSIMOS, D.G., et al., J. Urol., 192, nr. 2, 2014, p. 316

12.SKOLARIKOS, A., STRAUB, M., KNOLL, T., et al., Eur. Urol., 4, nr. 67,2015, p. 750

13.GEAVLETE, B.F., BRINZEA, A., CHECHERITA, I.A., ZURAC, S.A., GEORGESCU, D.A., BASTIAN, A.E., ENE, C.V., BULAI, C.A., GEAVLETE, D.O., ZAHARIA, M.R., GEAVLETE, P.A., Rom. J. Morphol. Embryol., 56, nr. 3, 2015, p. 1069

14.HIS, R.S., SANFORD, T., GOLDFARB, D.S., STOLLER, M.L., J. Urol., 4, nr. 197, 2017 p. 1084

15.PRICOP, C., SUDITU, N., VRINCEANU, R., PUIA, D., DIMITRIU, D.C., CIUTA, C., TODOSI, L., CHECHERITA, I.A., Nobel Med., 11, nr. 3, 2015, p. 42

16.RAO, N.P., PREMINGER, G.M., KAVANAGH, J.P., Urinary Tract Stone Disease, Springer-Verlag, LONDON, 2011
17.SRIBOONLUE, P., PRASONGWATTANA, V., TUNGSANGA, K., TOSUKHOW ONG, P., PHANTUMVANIT, P., BEJ RAPUTRA, O., SITPRIJA, V., Thailand Nephron, 4, nr. 59, 1991, p.591

18.MAHE, J.L., MOREL, J .A., CLEDES, J., BIGOT, J.C., BARDOU, L.G. Nephron, 4, nr. 62, 1992, p. 466

19.CHECHERITA, I.A., DAVID, C., CIOCALTEU, A., LASCAR, I., Chirurgia (Bucharest), 104, nr. 5, 2009, p. 525

20.BORGHI, L., MESCHI, T., AMATO, F., et al., J. Urol., 3, nr. 155, 1996, p. 839

21.HEILBERG, I.P., SCHOR, N., Arq. Bras. Endocrinol. Metab., 4, nr. 50,2006, p. 823

22.NICULAE, A., JINGA, M.A.R.I.A.N.A., CIOCÂLTEU, A., LASCÃR, I., JINGA, V., CHECHERIPÃ, I.A., Rom. J. Morphol. Embryol., 52, nr. 3, 2011, p. 863

23.TAYLOR, E.N., CURHAN, G.C.. Am. J. Kidney Dis., 6, nr. 48, 2006, p. 905

24.CIRILLO, M., LAURENZI, M., PANARELLI, W., STAMLER, J., Kidney Int., 4, nr. 46, 1994, p. 1133

25.CORDER, C.]., LESLIE, S.W., StatPearls [Internet]. StatPearls Publishing; Treasure Island (FL): 2018

26.EISNER, B.H., SHETH, S., DRETLER, S.P., et al., Urology, 4, nr. 80, 2012, p. 776

27.NICULAE, A., PERIDE, I., VINEREANU, V., RADULESCU, D., BRATU, O.G., GEAVLETE, B.F., CHECHERIPÃ, I.A., Rom. J. Morphol. Embryol., 58, nr. 3, 2017, p. 1065

28.DAUDON, M., JUNGERS, P., TRAXER, O., Lithiase urinaire (2e edition), Médecine Sciences Publications, 2012

29.PREMINGER, G.M., BAKER, S., PETERSON, R., POINDEXTER, J ., PAK, C.Y., J. Lith. Stone Dis., 1, nr. 2. 1989, p. 22.

30.ROBERTSON, W.G., HAMBLETON, J., HODGKINSON, A., Clin. Chim. Acta, 2, nr. 25, 1969, p. 247

31.HUSSEIN, N.S., SADIQ, S.M., KAMALIAH, M.D., NORAKMAL, A.W., GOHAR, M.N., Saudi J. Kidney Dis. Transpl., 3, nr. 24, 2013, p. 630 32.CHECHERITA, I.A., TURCU, F., DRAGOMIRESCU, R.F., CIOCALTEU, A., Rom. J. Morphol. Embryol., 51, nr. 1, 2010, p. 21

33.PERIDE, I., CHECHERITA, I.A., CIOCALTEU, A., LASCAR, I., Chirurgia (Bucharest), 106, nr. 1, 2011, p. 83

34.WU, W., YANG, D., TISELIUS, H.G., OU, L., et al., Urology, 4, nr. 83, 2014, p. 732

35.TISELIUS, H.G., LINDBÄCK, B., FORNANDER, A.M., et al., Urol. Res., 4, nr. 37, 2009, p. 181

36.FRIEDLANDER, J .I., MOREIRA, D.M., HARTMAN, C., ELSAMRA, S.E., SMITH, A.D., OKEKE Z., J. Endourol., 7, nr. 28, 2014, p. 871

$\overline{\text { Manuscript received:21.03.2018 }}$ 